\title{
Family Role in Facing the Prevalence of Terrorist Ideas among Adolescents
}

\author{
Huda AbdulAziz Aldegheiry \\ Assistant Professor of Case Work, \\ Social Work College, \\ Princess Nourah bint Abdulrahman University
}

Doi: $10.36941 /$ jesr-2019-0010

\begin{abstract}
The current study aimed at identifying family role in facing the prevalence of terrorist ideas among adolescents from the perspective of students, parents, and educational and intellectual security specialists. The descriptive analytical method was utilized in this study. The sample consisted of (92) students, (32) parents, and (14) educational and intellectual security specialists. Two electronic questionnaires were prepared. Results indicated that the most significant indicators of the prevalence of terrorist ideas among adolescents are provoking a fierce argument with family members who disagree with them and showing intolerance towards others. The most important causes that lead to the adoption of terrorist ideas by adolescents are the parents' lack of information about the friends of adolescents and about people whom they follow on social media. The most effective educational methods that should be adopted by the family to face the prevalence of terrorist ideas among adolescents are guiding them to respect the public rights and to choose the right companions. The study suggested raising awareness among parents about the developmental characteristics, behavioral problems, and social and psychological pressures of various age stages and preventing adolescents from watching porno movies.
\end{abstract}

Keywords: Family Role; Terrorist Ideas; Adolescents

\section{Introduction}

Terrorist thought is a social phenomenon that affects and is affected by others. It is deeply related to historical, political, religious, social, and economic circumstances. It reflects radical thought among some adolescents who adopt extremist fatwas that do not promote tolerance or accepting others. Thus, contemporary education is centered on and seeks the security of individuals and society, especially after the increasing rate of crimes and the prevalence of some negative phenomena like terrorism.

Family is the nucleus of society. It can detect and handle behavioral and ideological deviations among adolescents by doing its best. Adolescents' behavior, either positive or negative, primarily reflects the family's responsibility (AlBakmy, 2010). Therefore, religious upbringing and traditions create strong relationships among the Saudi family's members. That is, the strength and weakness of those relations highly affect social cohesion. The Basic Law of Governance in KSA (1992) formulated social dimensions focusing on those norms. In article 9 of chapter 3, it determines the constituents of Saudi society stating "the family is the nucleus of Saudi society. Members of the family shall be raised in the Islamic Creed, which demands allegiance and obedience to God, to His Prophet and to the rulers, respect for and obedience to the laws, and love for and pride in the homeland and its glorious history" (Alkhamshy, 2004).

Many studies, including AlMo'gel (2016), Attaweel (2016), AlMeleigy (2013), AIRashdy (2012), 
Halawa (2011), Assaleh (2008), Banjar (2006), AlHusseiny (2005) and Chemiss (2000), reported family role in facing the prevalence of terrorist ideas. Therefore, the Ministry of Islamic Affairs, Dawah and Guidance has started implementing a specialized family mission reinforcement program to protect adolescents against intellectual deviations in Jazan, AlJouf, Qassim, Asir and Eastern Region. It is being completed in other KSA regions. Despite the important family role in facing the prevalence of terrorist ideas among adolescents, some educational roles are ineffective. The role of Saudi family changed drastically over the last century and the first decade of the present one (AIMo'gel, 2016; AlBakmy, 2010; Sabbagh, 2005).

Terrorism is a global phenomenon which is not related to a specific region, culture, society or religious or ethnic groups. In the early $21^{\text {st }}$ century, there was a significant increase of terrorist operations. All countries have suffered from terrorism since the end of World War II which led to the emergence of left movements in Western Europe, France, Italy, Japan and other countries due to some ideas aiming at political change, especially at the end of 1960 s when terrorism prevailed. The effects of terrorism include the growth of terrorist groups whose harm extended outside their countries leading to wide-ranging terrorism known as international terrorism (Mustafa, 2008).

On Sep. $8^{\text {th }}, 2006$, the UN member states approved the Global Counter-Terrorism Strategy which is resolution and an annexed Plan of Action (A/RES/60/288), is a unique global instrument that will enhance national, regional and international efforts to counter terrorism. This is the first time that all the member states have agreed to a common strategy to combat terrorism, not only by sending a clear message condemning it but also by insisting on taking individual and collective practical steps (United Nations Office of Counter-Terrorism, 2006).

In late April 2007, security sectors discovered a terrorist scheme aiming at launching wideranging attacks in KSA. Terrorists were Saudi and other nationalities, suggesting that terrorist groups have worked on a wide-ranging regional level with various objectives. They aimed not only at bombing attacks but also at making a wide-ranging sabotage scheme causing great panic and horror (Mustafa, 2008). Recently, the crisis of terrorism has developed in KSA that more than 101 terrorist operations were executed; security sectors thwarted more than 38 attacks while 63 crimes were executed and resulted in 737 deaths and 1317 injuries from security, citizens, and inhabitants (AIMarwani, 2009).

In 2017, the Custodian of the Two Holy Mosques King Salman Bin Abdulaziz Al Saud, may Allah protect him, with the participation of the leaders of 55 countries, inaugurated the Global Center for Combating Extremist Ideology (Etidal) headquartered in Riyadh. Moreover, he launched the Ideological Warfare Center affiliated with the Saudi Ministry of Defense. His Majesty King Abdullah II, in his speech to the UN, highlighted the importance of disseminating the values of justice, love, and counter-terrorism and stressed that tolerance does not accept terrorism (Shradika, 2016).

Noteworthily, most of the perpetrators of such operations are young inhabitants. In addition, when official agencies announce their names and the names of those who helped them, their families feel shocked. It indicates that adolescents absorbed terrorist ideas away from family. Clearly, there is a gap in the family role towards their adolescents resulted from not following them (AlBakmy, 2010). Therefore, the present study aims at exploring family role in facing the prevalence of terrorist ideas among adolescents.

\section{Statement of the Problem}

The present study addresses terrorism in the Saudi society, primarily attributed to the lack of intellectual security which enables individuals to freely and fearlessly express their ideas and to the inflexibility of accepting others. That results in the prevalence of terrorist ideas and being away from moderate thinking which directly causes strife and conflicts that weaken the society. Furthermore, the harms of physical and intellectual terrorism are parallel. However, that dilemma is not scholarly tackled adequately. Therefore, family shall adopt the educational basics of moderate thinking because there are varied deviation routes and many doubtful matters. Actually, most studies of combating terrorist ideas generally tackle the role of school curricula, media, poverty, unemployment, or political factors only. Thus, the present study raises the following major question: 
What is the family role in facing the prevalence of terrorist ideas among adolescents?

It is subdivided into the following minor ones:

1. What are the indicators of the prevalence of terrorist ideas among adolescents?

2. What are the factors of the prevalence of terrorist ideas among adolescents?

3. What educational methods could be applied by the family to face the prevalence of terrorist ideas among adolescents?

4. What are the suggestions for activating family role in facing the prevalence of terrorist ideas among adolescents?

\subsection{Significance}

It is a significant study because it objectively responds to research centers for studying the prevalence and combating of terrorist ideas. It explores that phenomenon as a danger threatening the Saudi society and destabilizing its security. It highlights family role as an educational institution protecting its members against terrorist ideas. It also explores related educational studies. It provides two questionnaires about family role in facing the prevalence of terrorist ideas among adolescents for students, parents, and educational and intellectual security specialists. Moreover, it attempts to apply the Saudi Vision 2030 which focuses on counter-terrorism and taking care of family as a fundamental social unit. Finally, the study makes suggestions to activate family role in facing the prevalence of terrorist ideas among adolescents.

\subsection{Limitations}

- Spatial and human limitations: The study was applied to a group of families with adolescents aged 16 years and above, students (male and female) at governmental high schools, and educational and intellectual security specialists in Riyadh.

- Temporal limitations: Data were collected, analyzed, and discussed in 2017-2018.

- Subject limitations: The study is limited to exploring family role in facing the prevalence of terrorist ideas among adolescents.

\subsection{Theoretical Framework and Literature Review}

Factors of the prevalence of terrorist ideas among adolescents:

Facing the prevalence of terrorist ideas necessitates careful diagnosis by exploring the causes and motives to provide a suitable solution. According to Dawood (2015), Lazem (2015), Zain-ulabedeen (2015), Assa'eedyn (2008), AlJahni (2008a, 2008b), and AlMoisheer (2007), the factors overlap and vary. For example,

- The media play a significant role in disseminating or supporting terrorist ideas because the satellite channels, Internet, and newspaper may present destructive ideas supporting false freedom and terrorism.

- The bad company plays a vital role in absorbing terrorist ideas especially if it is a company of a profound effect on a weak and socially unstable person.

- The financial support is a strong means of financing, equipping, and supporting which facilitates getting, buying, or smuggling terrorism tools. In addition, modern technologies help highlight terrorism prevailing panic and horror.

- The absence of scholars' role helped non-efficient people get responsible for issuing false fatwas. Consequently, society gets destructed because people depend on them in understanding religion or despising their acts of devotion.

- The family and social disintegration because the adolescents' morals get corrupted in early ages due to the corrupted atmosphere that lacks proper family supervision and guidance. Also, tightfistedness and cruelty in early ages make them cruel and discontent with people and adopt terrorism as a means of revolting against their society.

- The psychological precipitants are related to the psychological wellbeing of adolescents, e.g. feeling of inferiority, hatred for society, and lack of factors that help achieve their 
dreams.

- The intellectual factors symbolize intellectual dissidents among different streams, nationally and internationally, leading to disagreement and prevalence of terrorist ideas.

- The deficiency of educational curricula as a source of guidance instilling values in adolescents because they are no more useful for students and society.

- The religious precipitants because the lack of correct understanding of religion and the inability to correctly understand the evidence derived from the Ever-Glorious Qur'an and Sunnah cause wrong religious practices.

The author believes that there are additional factors but she mentions the most significant ones. She does not want to justify the situation and acts of terrorists but to highlight the motives of terrorism in different societies to diagnose the problem and suggest a solution. Moreover, necessary counter-terrorism measures should be taken.

Consequences of the prevalence of terrorist ideas

The prevalence of terrorist ideas leads to deviation of adolescents making them hate building or protecting their homeland. Consequently, they become a tool for destruction and killing (Salem, 2018).

Family role in facing the prevalence of terrorist ideas among adolescents

AlKa'ood (2017), Abu Koora (2013), AlHaj (2011), and Mojahid (2005) argue that when families give up their role of raising children appropriately, children adopt terrorist ideas for many reasons, including:

- The intellectual role: Adolescents adopt terrorist thoughts due to the absence of proper intellectual impact. Family is primarily responsible for protecting adolescents against those ideas and guiding them towards beneficial ideas that serve the religion and nation.

- The family role: The characters, identities, and manners of adolescents are shaped by their families. Thus, parents shall raise them according to good morals and not focus on the pursuit of livelihood only.

- The social role: Family plays a significant role in society which is manifested at schools, cultural clubs, and governmental and civil associations where it has to guide adolescents to protect them against terrorist ideas. 2004):

Family role in protecting adolescents against terrorist ideas (Attaweel, 2016; AlMaghamsi,

a. Instilling appropriate values and concepts can be done through:

- Faith education by helping adolescents acquire Islamic values and attitudes and develop their capacities.

- Highlighting the virtues of Islam like compassion, tolerance, loving others, observance of rights, peace, cooperation, mercy, and avoiding injustice.

- Raising children to observe public rights, e.g. religion, oneself, money, and mind, to achieve security and stability in society by observing the rights of others and keeping public norm, morals, and health.

- Monitoring the ideas of adolescents, enhancing their manners by protecting them against all forms of intellectual deviation, and enhancing their intellectual immunity so that they could face intellectual challenges especially in the present global openness to all cultures.

- Reinforcing appropriate security manners and guiding adolescents to keep homeland security and acquisitions. Actually, all institutions- family, media, masjid, and schoolare responsible for keeping homeland properties because they are part of the homeland rights.

b- Adopting appropriate educational methods to defeat terrorist ideas such as advice, dialogue, wisdom, and fair exhortation.

c- Raising awareness among adolescents of ambient dangers through:

- Educating them about the prevalence of security as a basic human need and the dangers of the prevalence of terrorist ideas on homeland security.

- Protecting them against those who promote intellectual deviation and facing terrorist ideas broadcasted via the media by observing adolescents and raising their awareness 
of such ideas and combating them.

- Being cautious when surfing the Internet for it is a strong means of prevailing terrorist ideas because it dominates minds.

d- Understanding the features of human development. Usually, those who promote terrorist thoughts tend to exploit adolescents whereas there is no family awareness of the requirements of that development. Thus, they instill wrong concepts in them.

e- Raising adolescents on citizenship.

Consequently, the author deduces that a stable family produces well-behaved children with good manners. On the contrary, a dysfunctional family produces deviant children who do not abide by virtues because there are strong reasons to adopt terrorist ideas and do evil acts. Thus, they join extremist and terrorist groups.

\section{Literature Review}

Many studies tackled the important family role in facing the prevalence of terrorist ideas among adolescents. For example, Zain-ul-abedeen (2015) reported that the roles of family and religious institutions in preventing terrorist are intermediate. Moreover, the existing situations of the two roles have a reverse incorporeal effect on preventing terrorism that they provoke extremism and terrorism.

AlBakmy (2010) examined the relationship between parents and adolescents and its role in preventing intellectual deviation. Results showed that the poorer dialogue they have, the weaker the parents' role in preventing intellectual deviation becomes. AlHaj (2013) concluded that the intellectual deviations due to family are caused by weakly righteous education, including not monitoring adolescents, disintegration between family members, not meeting the needs of family members, deficient educational methods like excessive spoiling or cruelty, change in family roles, and poor dialogue between family members.

AlHawshan (2009) explored family and school roles in protecting adolescents against extremism and terrorism and reinforcing values of national belonging. The study assured that family is the basic nucleus of one's relationship with social life and it is the basic defense against deviation. It also examined the preaching family role in protecting them. AlKhalifa (2008) concluded that the families of terrorists are unstable and unable to keep their children discipline. This assures that poor family education leads to moral deviation at early ages. Additionally, AlJahni (2008a) reported that intellectual deviation is related to intolerance and unilateralism because social and family education in the Arab countries does not encourage dialogue. It is also related to poor family education due to the economic leap and contemporary developments which resulted in employing domestic workers, e.g. servants and drivers. Thus, young people become more dependent on others without bearing responsibility. Moreover, the present generations experience drastic changes in the acts of adolescents due to varied information sources. Therefore, family responsibility becomes more important than it was. Actually, allowing dialogue between family members and expressing opinions freely help parents to get clearer understanding of adolescents, correct wrong ideas, and guide them to correct ones.

AlJahni (2008b) reported the weak role of all kinds of social institutions in preventing terrorist ideas. Also, family education plays a significant role in defeating terrorist ideas by providing good examples, instilling belonging and loyalty, abiding by the religious values and basics, and instilling correct concepts in adolescents.

Assa'eedyn (2008) assured that family can prevent deviation because it has got two kinds of authority: preventive authority based on appropriate education of individuals on virtues and supervisory authority to protect adolescents against deviant ideas. AlMoisheer (2007) indicated some practices that protect adolescents against the prevalence of terrorist ideas: Following-up them at school or university, developing the concept of belonging, instilling respect between family members, avoiding family domestic disturbances, family awareness of the dominating society rules, following the key incidents in society, correctly understanding Islamic principles, and paying attention to the preventive family role of educating and socializing.

Assabea'y (2006) explored factors of the prevalence of terrorist thought, including the social 
emptiness and social isolation of adolescents and the weak role of international organizations in neutrally handling Islamic issues. Addagheem (2006) reported some means of terrorist thought, including Islamic education; some Masjid pulpits; some Qur'an memorizing sessions; Internet; and peer groups characterized by enthusiasm, emotional state, haste, and neglecting consequences. They help terrorists exploit adolescents easily.

Additionally, AlMaliky (2006) argued that the direct reasons for terrorism include religious extremism, intellectual deviation as well as political, personal, educational and economic reasons. Moreover, the media provocation stimulates hatred and extremism and some socialization institutions neglect perfectly performing their religious and educational tasks. AIGhamdy (2005) assured that the deficiency of family educational role because both or one of the parents are busy at work or they are of low educational level and being influenced by extremist thoughts are important reasons for the prevalence of terrorist thought. Assa'eedyn (2005) concluded that terrorism is caused by some economic, social, and family reasons due to poor understanding of Sharia and aimless free time. Thus, a family can prevent terrorist ideas by instilling and developing principles like moderate thinking, dialogue, tolerance, and work.

\section{Methodology}

\subsection{Method}

The present study adopts the descriptive analytical method as the most appropriate for the nature of the study because it studies the phenomenon as is in reality.

\subsection{Population and sampling}

The population includes all families with adolescents aged 16 years and above, all students (male and female) at governmental high schools, and educational and intellectual security specialists in Riyadh.

The sample comprises 32 parents (16 fathers and 16 mothers), 92 students (30 males and 62 females), and 14 specialists.

\subsection{Tools}

The author prepared two electronic questionnaires (one for students and the other for parents and specialists) in order to identify family role in facing the prevalence of terrorist ideas among adolescents. Aims, domains, and items of the questionnaires were set. The final draft of the first questionnaire included 12 items for the first domain, 20 for the second, 17 for the third and 14 for the fourth. The final draft of the second questionnaire comprised 52 items.

\subsubsection{Validity and reliability of the students' questionnaire}

\subsubsection{Validity}

Reviewers' validity: The questionnaire was reviewed by a group of specialists at Saudi universities in order to express their opinion about its validity, item appropriateness, scientific and linguistic accuracy and to recommend modifications. Based on their notes, some items were added, merged, deleted, or modified.

Internal validity: The correlation coefficients between the score of each item and its domain were calculated in the pilot sample. Results are shown in Table (1). 
Table (1): The correlation coefficients between each item and its domain

\begin{tabular}{|c|c|c|c|}
\hline No. & Correlation coefficient & No. & Correlation coefficient \\
\hline \multicolumn{4}{|c|}{ First domain } \\
\hline 1 & $0.66^{*}$ & 7 & $0.58^{*}$ \\
\hline 2 & $0.63^{*}$ & 8 & 0.27 \\
\hline 3 & 0.01 & 9 & $0.73^{*}$ \\
\hline 4 & 0.68 & 10 & $0.40^{*}$ \\
\hline 5 & 0.37 & 11 & 0.16 \\
\hline 6 & 0.63 & & \\
\hline \multicolumn{4}{|c|}{ Second domain } \\
\hline 1 & $0.72^{*}$ & 8 & $0.80^{*}$ \\
\hline 2 & $0.90^{*}$ & 9 & 0.57 \\
\hline 3 & $0.80^{*}$ & 10 & $0.75^{*}$ \\
\hline 4 & $0.54^{*}$ & 11 & 0.22 \\
\hline 5 & $0.63^{*}$ & 12 & $0.93^{*}$ \\
\hline 6 & $0.72^{*}$ & 13 & $0.71^{*}$ \\
\hline 7 & $0.80^{*}$ & 14 & $0.82^{*}$ \\
\hline \multicolumn{4}{|c|}{ Third domain } \\
\hline 1 & $0.83^{*}$ & 9 & $0.68^{*}$ \\
\hline 2 & $0.50^{*}$ & 10 & $0.86^{*}$ \\
\hline 3 & $0.74^{*}$ & 11 & $0.55^{\star}$ \\
\hline 4 & $0.73^{*}$ & 12 & $0.46^{*}$ \\
\hline 5 & $0.81^{*}$ & 13 & $0.53^{*}$ \\
\hline 6 & $0.55^{*}$ & 14 & $0.64^{*}$ \\
\hline 7 & $0.75^{*}$ & 15 & $0.79^{*}$ \\
\hline 8 & $0.72^{*}$ & & \\
\hline \multicolumn{4}{|c|}{ Fourth domain } \\
\hline 1 & $0.67^{*}$ & 6 & $0.75^{*}$ \\
\hline 2 & $0.84^{*}$ & 7 & $0.70^{*}$ \\
\hline 3 & $0.83^{*}$ & 8 & $0.53^{*}$ \\
\hline 4 & $0.48^{*}$ & 9 & $0.71^{*}$ \\
\hline 5 & $0.77^{*}$ & 10 & $0.52^{*}$ \\
\hline
\end{tabular}

Table (1) indicates that there are statistically significant differences at the level of 0.05 except for items $(3,5,9$, and 11$)$ in the first domain and item (11) in the second. Thus, the author excluded them. After modifications, the questionnaire consisted of (46) items.

\subsubsection{Reliability}

The questionnaire was applied to a pilot sample, then the Cronbach's Alpha was calculated. Results are shown in Table (2).

Table (2): The questionnaire's reliability coefficient

\begin{tabular}{|l|c|c|}
\hline Domain & No. of items & Cronbach's Alpha \\
\hline First & 7 & 0.80 \\
\hline Second & 13 & 0.92 \\
\hline Third & 15 & 0.92 \\
\hline Fourth & 10 & 0.87 \\
\hline Total & 46 & 0.86 \\
\hline
\end{tabular}

Table (2) indicates that the questionnaire's reliability coefficient is high and rates 0.86 . The reliability coefficients of the four domains were in the range of $0.80-0.92$, suggesting that the questionnaire is highly reliable. 


\subsubsection{Validity and reliability of the questionnaire of parents and specialists}

\subsubsection{Validity}

Reviewers' validity: The questionnaire was reviewed by a group of specialists at Saudi universities in order to express their opinion about its validity, item appropriateness, scientific and linguistic accuracy and to recommend modifications. Based on their notes, some items were added, merged, deleted, or modified.

Internal validity: The correlation coefficients between the score of each item and its domain were calculated in the pilot sample. Results are shown in Table (3).

Table (3): The correlation coefficients between the item and its domain

\begin{tabular}{|c|c|c|c|}
\hline No. & Correlation coefficient & No. & Correlation coefficient \\
\hline \multicolumn{4}{|c|}{ First domain } \\
\hline 1 & $0.67^{*}$ & 7 & $0.70^{*}$ \\
\hline 2 & $0.86^{*}$ & 8 & $0.79^{*}$ \\
\hline 3 & $0.68^{*}$ & 9 & $0.74^{*}$ \\
\hline 4 & $0.68^{*}$ & 10 & $0.57^{*}$ \\
\hline 5 & $0.50^{*}$ & 11 & $0.62^{*}$ \\
\hline 6 & $0.69^{*}$ & 12 & $0.53^{*}$ \\
\hline \multicolumn{4}{|c|}{ Second domain } \\
\hline 1 & 0.22 & 11 & $0.58^{*}$ \\
\hline 2 & 0.36 & 12 & $0.52^{*}$ \\
\hline 3 & $0.59^{*}$ & 13 & $0.52^{*}$ \\
\hline 4 & $0.50^{*}$ & 14 & $0.69^{*}$ \\
\hline 5 & $0.59^{*}$ & 15 & $0.56^{*}$ \\
\hline 6 & $0.65^{\star}$ & 16 & $0.79^{*}$ \\
\hline 7 & 0.06 & 17 & $0.80^{*}$ \\
\hline 8 & $0.78^{*}$ & 18 & 0.37 \\
\hline 9 & $0.63^{*}$ & 19 & 0.49 \\
\hline 10 & $0.52^{\star}$ & 20 & $0.78^{*}$ \\
\hline \multicolumn{4}{|c|}{ Third domain } \\
\hline 1 & $0.69^{*}$ & 10 & $0.67^{*}$ \\
\hline 2 & $0.41^{*}$ & 11 & $0.88^{*}$ \\
\hline 3 & $0.57^{*}$ & 12 & $0.58^{*}$ \\
\hline 4 & 0.34 & 13 & $0.63^{*}$ \\
\hline 5 & $0.83^{*}$ & 14 & $0.81^{*}$ \\
\hline 6 & $0.85^{\star}$ & 15 & $0.70^{*}$ \\
\hline 7 & $0.77^{*}$ & 16 & $0.72^{*}$ \\
\hline 8 & $0.90^{*}$ & 17 & $0.69^{*}$ \\
\hline 9 & $0.85^{*}$ & & \\
\hline \multicolumn{4}{|c|}{ The fourth domain } \\
\hline 1 & $0.61^{*}$ & 8 & $0.57^{\star}$ \\
\hline 2 & $0.57^{*}$ & 9 & $0.75^{\star}$ \\
\hline 3 & $0.61^{*}$ & 10 & $0.79^{*}$ \\
\hline 4 & $0.78^{*}$ & 11 & 0.38 \\
\hline 5 & $0.75^{*}$ & 12 & $0.47^{*}$ \\
\hline 6 & $0.75^{*}$ & 13 & 0.17 \\
\hline 7 & $0.65^{*}$ & 14 & $0.52^{*}$ \\
\hline
\end{tabular}

Table (3) indicates that there are statistically significant differences at the level of 0.05 except for items $(1,2,7$, and 18) in the second domain, item (4) in the questionnaire. After modifications, the questionnaire consisted of (12) items for the first domain, (16) items for the second, (16) items for the third, and (12) items for the fourth. 


\subsubsection{Reliability}

The questionnaire was applied to a pilot sample then the Cronbach's Alpha was calculated. Results are shown in Table (4).

Table (4): The questionnaire's reliability coefficient

\begin{tabular}{|l|c|c|}
\hline Domain & No. of items & Cronbach's Alpha $(\alpha)$ \\
\hline First & 12 & 0.88 \\
\hline Second & 20 & 0.87 \\
\hline Third & 17 & 0.93 \\
\hline Fourth & 14 & 0.86 \\
\hline Total & 63 & 0.93 \\
\hline
\end{tabular}

Table (4) shows that the questionnaire's reliability coefficient is high and rates 0.93 . The reliability coefficients of the four domains were in the range of $0.86-0.93$, suggesting that the questionnaire is highly reliable.

\section{Results and Discussion}

\subsection{Results of the first questionnaire}

In order to answer the first question from the perspective of students, the arithmetic means and standard deviations were calculated.

Table (5): Means of students' responses to the first question

\begin{tabular}{|c|l|c|c|c|c|}
\hline No. & Item & Mean & $\begin{array}{c}\text { Standard } \\
\text { Deviation }\end{array}$ & Response & Ranking \\
\hline 1 & I hold my opinion and do not accept others. & 1.11 & 0.35 & Disagree & 2 \\
\hline 2 & I utter bad words when talking with others. & 1.61 & 0.59 & Disagree & 6 \\
\hline 3 & I make troubles with my family because I have different ideas. & 1.42 & 0.63 & Disagree & 4 \\
\hline 4 & I passionately follow websites away from my family. & 1.39 & 0.64 & Disagree & 3 \\
\hline 5 & I do not have any cultural or social activity in society. & 1.54 & 0.64 & Disagree & 5 \\
\hline 6 & I never forgive those who hurt me. & 1.08 & 0.31 & Disagree & 1 \\
\hline 7 & I aggressively talk with my parents. & 1.65 & 0.65 & Disagree & 7 \\
\hline Overall & 1.65 & 0.65 & Disagree \\
\hline
\end{tabular}

Table (5) shows significant indicators of the prevalence of terrorist ideas among students. Those who adopt terrorist ideas are perhaps highly intolerant and do not easily forgive those who harm them because they do not have good morals. Additionally, they hold their own opinions without accepting others' opinions or criticism, so they are extremist. This is a basic characteristic of groups adopting terrorist ideas. Also, they passionately follow social media without parents' supervision. This result accords with AlHaj (2013), AlJahni (2008a), Addagheem (2006) and AlMaliky (2006). In order to answer the second question from the perspective of students, arithmetic means and standard deviations were calculated.

Table (6): Means of students' responses to the second question

\begin{tabular}{|c|l|c|c|c|c|}
\hline No. & Item & Mean & $\begin{array}{c}\text { Standard } \\
\text { Deviation }\end{array}$ & Response & Ranking \\
\hline 1 & My parents do not adhere to religion. & 1.49 & 0.69 & Disagree & 13 \\
\hline 2 & My parents do not pay attention to correct my wrong acts. & 1.29 & 0.55 & Disagree & 10 \\
\hline 3 & My parents always hit me. & 1.22 & 0.49 & Disagree & 8 \\
\hline 4 & My parents are always busy. & 1.13 & 0.42 & Disagree & 5 \\
\hline
\end{tabular}




\begin{tabular}{|c|l|c|c|l|c|}
\hline No. & Item & Mean & $\begin{array}{c}\text { Standard } \\
\text { Deviation }\end{array}$ & Response & Ranking \\
\hline 5 & My parents do not care about my educational level. & 1.16 & 0.52 & Disagree & 6 \\
\hline 6 & My father encourages me to despise others. & 1.25 & 0.55 & Disagree & 9 \\
\hline 7 & There are no good examples in my family. & 1.33 & 0.60 & Disagree & 11 \\
\hline 8 & My parents do not guide me to tolerate or love others. & 1.39 & 0.59 & Disagree & 12 \\
\hline 9 & My family has no idea about whom I follow on social media. & 1.76 & 0.78 & $\begin{array}{l}\text { Slightly } \\
\text { agree }\end{array}$ & 1 \\
\hline 10 & My parents always quarrel. & 1.13 & 0.42 & Disagree & 4 \\
\hline 11 & $\begin{array}{l}\text { My parents prevent me from participating in any sports, } \\
\text { cultural or social activities. }\end{array}$ & 1.21 & 0.46 & Disagree & 7 \\
\hline 12 & My parents do not care about what I read. & 1.07 & 0.29 & Disagree & 2 \\
\hline 13 & $\begin{array}{l}\text { My parents do not help me to develop critical thinking or } \\
\text { problem-solving skills. }\end{array}$ & 1.11 & 0.44 & Disagree & 3 \\
\hline Overall & 1.27 & 0.34 & Disagree \\
\hline
\end{tabular}

Table (6) presents significant results of the prevalence of terrorist ideas among adolescents. One reason is that parents do not know much about their adolescents' activity on the social media who seeks someone with similar ideas, so they become easy prey to extremist groups, especially with absent parents' supervision. Another reason is that families do not follow what adolescents read. Parents and specialists agree that it is a major reason. A third reason is that parents do not help adolescents develop critical thinking and problem-solving skills to think moderately, differentiate between good and evil and not to adopt opinions without considering them rationally. Acquiring those skills protects adolescents against negative intellectual subordination. Parents can develop those skills by proper dialogue with them. They also need to train adolescents on expressing and discussing ideas, self-dependence, and self-confidence that enable them to face problems courageously and creatively. This result accords with AlHaj (2013), AlJahni (2008a), Addagheem (2006) and AIMaliky (2006).

To answer the third question from the perspective of students, arithmetic means and standard deviations were calculated.

Table (7): Means of students' responses to the third question

\begin{tabular}{|c|l|c|c|l|c|}
\hline No. & Item & Mean & $\begin{array}{c}\text { Standard } \\
\text { Deviation }\end{array}$ & Response & Ranking \\
\hline 1 & My parents develop my citizenship and national belonging. & 2.66 & 0.60 & Completely agree & 5 \\
\hline 2 & My mother accompanies me when buying books. & 1.76 & 0.78 & Slightly agree & 15 \\
\hline 3 & My parents guide me to differentiate between right and wrong. & 2.73 & 0.53 & Completely agree & 3 \\
\hline 4 & My parents inquire about my educational level. & 2.39 & 0.71 & Completely agree & 10 \\
\hline 5 & $\begin{array}{l}\text { My father discusses with me when I have a different point of } \\
\text { view. }\end{array}$ & 2.37 & 0.64 & Completely agree & 12 \\
\hline 6 & My parents adhere to positive social traditions. & 2.68 & 0.51 & Completely agree & 4 \\
\hline 7 & My mother guides me to choose good friends. & 2.75 & 0.51 & Completely agree & 1 \\
\hline 8 & My parents train me to bear responsibility. & 2.64 & 0.62 & Completely agree & 6 \\
\hline 9 & My parents tell me about the risks of terrorism. & 2.39 & 0.74 & Completely agree & 11 \\
\hline 10 & $\begin{array}{l}\text { My parents guide me to do sports and read to spend my } \\
\text { free time usefully. }\end{array}$ & 2.40 & 0.71 & Completely agree & 9 \\
\hline 11 & My parents train me on balancing between mind and heart. & 2.42 & 0.68 & Completely agree & 8 \\
\hline 12 & My parents follow my online activity. & 1.99 & 0.78 & Slightly agree & 14 \\
\hline 13 & My parents always advise and guide me. & 2.75 & 0.51 & Completely agree & 2 \\
\hline 14 & My family deepens intellectual tolerance in me. & 2.54 & 0.62 & Completely agree & 7 \\
\hline 15 & My family encourages me to join cultural and social events. & 2.29 & 0.70 & Slightly agree & 13 \\
\hline Overall & 2.45 & 0.42 & Completely agree \\
\hline
\end{tabular}

Table (7) shows significant educational methods that could be applied by family to face the prevalence of terrorist ideas among adolescents. It is important for parents to raise adolescents' 
awareness of the risks of bad company and how to choose good friends. Similarly important is proper education by guiding adolescents in all life choices. Then, they have to help adolescents differentiate between right and wrong to avoid terrorist ideas. Finally, there is sticking to positive traditions such as honesty, justice, and respecting other opinions. Such methods help protect adolescents against any deviation and hence society becomes more stable and safer. This result matches AlHaj (2013), AlJahni (2008a, 2008b), Assa'eedyn (2008), AlMoisheer (2007) and Assa'eedyn (2005).

In order to answer the fourth question from the perspective of students, arithmetic means and standard deviations were calculated.

Table (8): Means of students' responses to the fourth question

\begin{tabular}{|c|l|c|c|c|c|}
\hline No. & Item & Mean & $\begin{array}{l}\text { Standard } \\
\text { Deviation }\end{array}$ & Response & Ranking \\
\hline 1 & My parents should know about intellectual safety. & 2.64 & 0.55 & Completely agree & 7 \\
\hline 2 & $\begin{array}{l}\text { My parents should motivate me to participate in religious } \\
\text { and national events. }\end{array}$ & 2.64 & 0.55 & Completely agree & 8 \\
\hline 3 & $\begin{array}{l}\text { My parents should help me spend free time usefully (e.g. } \\
\text { in a library or a club). }\end{array}$ & 2.64 & 0.60 & Completely agree & 9 \\
\hline 4 & $\begin{array}{l}\text { My parents should adopt proper dialogue in discussing } \\
\text { problems }\end{array}$ & 2.74 & 0.49 & Completely agree & 6 \\
\hline 5 & $\begin{array}{l}\text { My parents should guide me about the risks of bad } \\
\text { company. }\end{array}$ & 2.78 & 0.51 & Completely agree & 5 \\
\hline 6 & $\begin{array}{l}\text { My family should help me criticize constructively and } \\
\text { accept others' opinions }\end{array}$ & 2.79 & 0.41 & Completely agree & 4 \\
\hline 7 & My family should help me understand religion correctly. & 2.80 & 0.50 & Completely agree & 3 \\
\hline 8 & $\begin{array}{l}\text { My parents should monitor my behavior inside and } \\
\text { outside the house. }\end{array}$ & 2.50 & 0.62 & Completely agree & 10 \\
\hline 9 & My mother must prevent me from watching porno movies. & 2.89 & 0.35 & Completely agree & 1 \\
\hline 10 & My family should understand my needs and interests. & 2.83 & 0.43 & Completely agree & 2 \\
\hline Overall & 2.72 & 0.30 & Completely agree \\
\hline
\end{tabular}

Table (8) highlights significant suggestions for activating family role in facing the prevalence of terrorist ideas among adolescents from the perspective of students. Most significantly, family should monitor adolescents' behaviors and prevent them from watching porno movies. Then, training courses should be offered to families to raise their awareness of the needs and interests of adolescents. Reinforcing religious consciousness among adolescents and correctly explaining religion to them was ranked third. There are other suggestions as ordered in the table. This result agrees with AlHaj (2013), AlJahni (2008a, 2008b), Addagheem (2006) and AlMaliky (2006).

\subsection{Results of the second questionnaire}

In order to answer the first question from the perspective of parents and specialists, arithmetic means and standard deviations were calculated.

Table (9): Means of the responses of parents and specialists to the first question

\begin{tabular}{|c|l|c|c|c|c|}
\hline No. & Item & Mean & $\begin{array}{c}\text { Standard } \\
\text { Deviation }\end{array}$ & Response & Ranking \\
\hline 1 & $\begin{array}{l}\text { Adolescents adopting terrorist thought are not proud of } \\
\text { their home and history. }\end{array}$ & 2.38 & 0.61 & Completely agree & 3 \\
\hline 2 & $\begin{array}{l}\text { Adolescents adopting terrorist thought provoke a fierce } \\
\text { argument with family members who disagree with them. }\end{array}$ & 2.44 & 0.56 & Completely agree & 1 \\
\hline 3 & $\begin{array}{l}\text { Adolescents adopting terrorist thought usually watches } \\
\text { movies calling for violence and extremism. }\end{array}$ & 2.31 & 0.59 & Slightly agree & 5 \\
\hline 4 & $\begin{array}{l}\text { Adolescents adopting terrorist thought do not abide by } \\
\text { basic morals and traditions. }\end{array}$ & 1.81 & 0.78 & Slightly agree & 12 \\
\hline
\end{tabular}




\begin{tabular}{|c|l|c|c|l|c|}
\hline No. & Item & Mean & $\begin{array}{l}\text { Standard } \\
\text { Deviation }\end{array}$ & Response & Ranking \\
\hline 5 & $\begin{array}{l}\text { Adolescents adopting terrorist thought spend free time } \\
\text { uselessly. }\end{array}$ & 2.19 & 0.59 & Slightly agree & 7 \\
\hline 6 & $\begin{array}{l}\text { Adolescents adopting terrorist thought utter bad and } \\
\text { aggressive words which affect their relationships with } \\
\text { family and society. }\end{array}$ & 2.13 & 0.55 & Slightly agree & 8 \\
\hline 7 & $\begin{array}{l}\text { Adolescents adopting terrorist thought act in a completely } \\
\text { free way without family guidance. }\end{array}$ & 2.06 & 0.72 & Slightly agree & 10 \\
\hline 8 & $\begin{array}{l}\text { Adolescents adopting terrorist thought deal selfishly with } \\
\text { family. }\end{array}$ & 2.06 & 0.62 & Slightly agree & 9 \\
\hline 9 & $\begin{array}{l}\text { Adolescents adopting terrorist thought do not set aims or } \\
\text { ambitions for their lives. }\end{array}$ & 2.28 & 0.77 & Slightly agree & 6 \\
\hline 10 & $\begin{array}{l}\text { Adolescents adopting terrorist thought do not accept } \\
\text { criticism. }\end{array}$ & 2.34 & 0.48 & Completely agree & 4 \\
\hline 11 & $\begin{array}{l}\text { Adolescents adopting terrorist thought are usually } \\
\text { neglected by their parents. }\end{array}$ & 1.94 & 0.72 & Slightly agree & 11 \\
\hline 12 & $\begin{array}{l}\text { Adolescents adopting terrorist thought avoid family } \\
\text { atmosphere. }\end{array}$ & 2.41 & 0.61 & Completely agree & 2 \\
\hline Overall & 2.20 & 0.44 & Slightly agree \\
\hline
\end{tabular}

Table (9) presents significant indicators that adolescents are subject to adopt terrorist ideas. Firstly, they disrespect others' opinions and strictly stick to their own opinions even they are wrong. They are introvert and avoid family atmosphere. They do not feel proud of their country. Those traits are basically acquired through family education and socialization. If they are neglected by family, adolescents become weak and unpatriotic preferring to be isolated from society. Hence, they easily adopt terrorist ideas that satisfy their needs. Moreover, when a family treats their adolescents rigidly or indulgently, they become less self-confident and less self-dependent, so they do not trust their society.

However, the following indicators are less important from the perspective of the participants: Adolescents adopting terrorist thought do not abide by basic morals and traditions, adolescents adopting terrorist thought are usually neglected by their parents, and adolescents adopting terrorist thought act in a completely free way without family guidance. Furthermore, the participants added some indicators like the sudden change of friends, underestimating the opinions of tolerant scholars, low achievement, and inappropriately understanding religion. This result accords with AlHawshan (2008), AlJahni (2008a, 2008b), AlMoisheer (2007) and Assabea'y (2007).

To answer the second question from the perspective of parents and educational and intellectual security specialists, arithmetic means and standard deviations were calculated.

Table (10): Means of the responses of parents and specialists to the second question

\begin{tabular}{|c|l|c|c|l|c|}
\hline No. & Item & Mean & $\begin{array}{l}\text { Standard } \\
\text { Deviation }\end{array}$ & $\begin{array}{l}\text { Response } \\
\text { Ranking }\end{array}$ \\
\hline 1 & Parents are cruel and punish adolescents. & 2.03 & 0.59 & Slightly agree & 15 \\
\hline 2 & Parents do not know adolescents' friends. & 2.66 & 0.48 & Completely agree & 1 \\
\hline 3 & Family lacks social consciousness. & 2.31 & 0.64 & Slightly agree & 7 \\
\hline 4 & Parents admire a figure adopting extremist ideas. & 1.94 & 0.80 & Slightly agree & 16 \\
\hline 5 & $\begin{array}{l}\text { Parents guide adolescents to stick to proper religious } \\
\text { principles. }\end{array}$ & 2.31 & 0.53 & Slightly agree & 6 \\
\hline 6 & Parents do not like to be argued. & 2.28 & 0.63 & Slightly agree & 8 \\
\hline 7 & Parents cannot resolve family issues. & 2.28 & 0.63 & Slightly agree & 9 \\
\hline 8 & $\begin{array}{l}\text { Family members refuse to deal with those who adopt } \\
\text { different religions. }\end{array}$ & 2.06 & 0.62 & Slightly agree & 14 \\
\hline 9 & Giving orders is the favorite method for parents. & 2.12 & 0.55 & Slightly agree & 11 \\
\hline 10 & Parents do not follow what adolescents read. & 2.63 & 0.55 & Completely agree & 2 \\
\hline 11 & $\begin{array}{l}\text { Parents do not guide adolescents about the limits of } \\
\text { personal freedom. }\end{array}$ & 2.47 & 0.57 & Completely agree & 3 \\
\hline
\end{tabular}




\begin{tabular}{|c|l|c|c|l|c|}
\hline No. & Item & Mean & $\begin{array}{l}\text { Standard } \\
\text { Deviation }\end{array}$ & Response & Ranking \\
\hline 12 & Some families are ignorant. & 2.09 & 0.73 & Slightly agree & 13 \\
\hline 13 & Parents are not tolerant of adolescents. & 2.09 & 0.64 & Slightly agree & 12 \\
\hline 14 & Parents do not protect adolescents against intolerance. & 2.40 & 0.61 & Completely agree & 4 \\
\hline 15 & Parents do not respect the social norm. & 2.16 & 0.72 & Slightly agree & 10 \\
\hline 16 & $\begin{array}{l}\text { Parents are not adequately aware of how to deal } \\
\text { appropriately with adolescents. }\end{array}$ & 2.34 & 0.54 & Completely agree & 5 \\
\hline Overall & 2.23 & 0.33 & Slightly agree \\
\hline
\end{tabular}

Table (10) shows significant family deficiencies which lead to the prevalence of terrorist ideas among adolescents. For example, parents do not know adolescents' friends, they do not follow what adolescents read and they do not guide them about the limits of personal freedom. These reasons indicate the absence of parents' role in monitoring and following-up adolescents and suggest their educational deficiency, directly leading to the prevalence of terrorist ideas among adolescents. The bad company deeply affects adolescents because friends imitate each other. Furthermore, reading books without parents' supervision is another serious family deficiency because they look in books for people with similar characteristics which make them subject to extremist reading that promotes hatred and negatively affects their ideologies. It becomes more dangerous when adolescents take those ideas for granted. One more reason is that parents do not guide adolescents about personal freedom which makes them selfish without taking others into consideration. They act as they like even if they harm others. Hence, they become subject to adopt terrorist ideas. The participants agreed that the following reasons are quite less important: Parents admire a figure who adopts extremist ideas, they are cruel and punish adolescents, and they are not tolerant with adolescents. The participants added some factors such as the lack of family education that guides to watch one's actions if they stick to Allah's creed or not and the lack of monitoring what adolescents follow on social media. This result matches the findings of AlHaj (2013), AlJahni (2008a, 2008b) Assa'eedyn (2008), AlMoisheer (2007) and Assa'eedyn (2005).

To answer the third question from the perspective of parents and specialists, arithmetic means and standard deviations were calculated.

Table (11): Means of the responses of parents and specialists to the third question

\begin{tabular}{|c|l|c|c|c|c|}
\hline No. & Item & Mean & $\begin{array}{c}\text { Standard } \\
\text { Deviation }\end{array}$ & Response & Ranking \\
\hline 1 & $\begin{array}{l}\text { Parents reinforce the value of cooperation among } \\
\text { adolescents in family and national events. }\end{array}$ & 2.63 & 0.49 & Completely agree & 14 \\
\hline 2 & Parents guide adolescents to make good friends. & 2.81 & 0.47 & Completely agree & 4 \\
\hline 3 & Parents raise adolescents to respect public rights. & 2.88 & 0.34 & Completely agree & 1 \\
\hline 5 & Parents instill intellectual tolerance among adolescents. & 2.78 & 0.42 & Completely agree & 5 \\
\hline 6 & $\begin{array}{l}\text { Parents highlight the religious role in developing appropriate } \\
\text { thoughts. }\end{array}$ & 2.81 & 0.40 & Completely agree & 3 \\
\hline 7 & Parents develop security sense among adolescents. & 2.78 & 0.49 & Completely agree & 6 \\
\hline 8 & Parents develop rational thinking based on evidence. & 2.72 & 0.52 & Completely agree & 12 \\
\hline 9 & Parents listen to adolescents' problems. & 2.84 & 0.37 & Completely agree & 2 \\
\hline 10 & Parents encourage adolescents to deal with others equally. & 2.72 & 0.46 & Completely agree & 10 \\
\hline 11 & Parents occasionally follow-up adolescents' educational level. & 2.75 & 0.44 & Completely agree & 8 \\
\hline 12 & Parents educate adolescents politically and culturally. & 2.63 & 0.61 & Completely agree & 14 \\
\hline 13 & Parents provide adolescents with advice and guidance. & 2.72 & 0.46 & Completely agree & 11 \\
\hline 14 & $\begin{array}{l}\text { Parents develop individual responsibility and decision- } \\
\text { making among adolescents. }\end{array}$ & 2.75 & 0.44 & Completely agree & 9 \\
\hline 15 & Parents discuss different intellectual matters with adolescents. & 2.47 & 0.57 & Completely agree & 15 \\
\hline 16 & Parents guide adolescents to usefully spend free time. & 2.71 & 0.46 & Completely agree & 13 \\
\hline 17 & $\begin{array}{l}\text { Parents are well-aware of the characteristics, needs, and } \\
\text { interests of adolescents. }\end{array}$ & 2.78 & 0.49 & Completely agree & 7 \\
\hline Overall & 2.73 & 0.32 & Completely agree \\
\hline
\end{tabular}


Table (11) illustrates significant educational methods that could be applied by family to face the prevalence of terrorist ideas among adolescents. They include raising adolescents to respect public rights through moral education and socialization, listening to their problems, and highlighting the religious role in guiding them to appropriate thinking. Family plays a significant role through the good religious and intellectual education of adolescents which protects them against terrorist ideas. It also helps them not to adopt ideas that are against religion and society. When a family successfully plays its roles in preventing the prevalence of terrorist ideas, it maintains family and social peace. This result agrees with AlHaj (2013), AlBakmy (2010), AlJahni (2008a, 2008b), Assa'eedyn (2008), AlMoisheer (2007), AlMaliky (2006) and Assa'eedyn (2005).

To answer the fourth question from the perspective of parents and specialists, arithmetic means and standard deviations were calculated.

Table (12): Means of the responses of parents and specialists to the fourth question

\begin{tabular}{|c|c|c|c|c|c|}
\hline No. & Item & Mean & $\begin{array}{l}\text { Standard } \\
\text { Deviation }\end{array}$ & Response & Ranking \\
\hline 1 & $\begin{array}{l}\text { Family reinforces religious consciousness, confirms } \\
\text { moderate ideas, and avoids exaggeration among } \\
\text { adolescents. }\end{array}$ & 2.90 & 0.30 & Completely agree & 6 \\
\hline 2 & $\begin{array}{l}\text { Family educates adolescents about values and } \\
\text { traditions that regulate individual behavior in society. }\end{array}$ & 2.90 & 0.30 & Completely agree & 7 \\
\hline 3 & $\begin{array}{l}\text { Parents' awareness of the developmental characteristics, } \\
\text { behavioral problems, and social and psychological } \\
\text { pressures of various age stages should be raised. }\end{array}$ & 2.94 & 0.25 & Completely agree & 1 \\
\hline 4 & $\begin{array}{l}\text { Parents highlight risks of terrorist ideas adopted by } \\
\text { contemporary ideological streams which threaten } \\
\text { intellectual security. }\end{array}$ & 2.84 & 0.37 & Completely agree & 8 \\
\hline 5 & $\begin{array}{l}\text { Parents raise adolescents to discuss disputes and } \\
\text { accept solutions. }\end{array}$ & 2.81 & 0.40 & Completely agree & 9 \\
\hline 6 & $\begin{array}{l}\text { Family employs religious and national events to instill } \\
\text { appropriate thinking among adolescents. }\end{array}$ & 2.69 & 0.47 & Completely agree & 12 \\
\hline 7 & $\begin{array}{l}\text { Parents respect adolescents through respecting and } \\
\text { appreciating their opinions. }\end{array}$ & 2.91 & 0.30 & Completely agree & 4 \\
\hline 8 & $\begin{array}{l}\text { Parents should be educated on practices of good } \\
\text { socialization in a way that respects social positive } \\
\text { traditions. }\end{array}$ & 2.91 & 0.30 & Completely agree & 5 \\
\hline 9 & $\begin{array}{l}\text { Parents help adolescents acquire effective } \\
\text { communication, constructive criticism, and problem- } \\
\text { solving skills. }\end{array}$ & 2.81 & 0.40 & Completely agree & 10 \\
\hline 10 & $\begin{array}{l}\text { Parents develop a sense of pride of achievements by } \\
\text { creative scientists and intellectuals. }\end{array}$ & 2.72 & 0.46 & Completely agree & 11 \\
\hline 12 & $\begin{array}{l}\text { Parents develop a sense of national belonging and } \\
\text { loyalty to confirm nationalism and citizenship. }\end{array}$ & 2.94 & 0.25 & Completely agree & 2 \\
\hline 14 & $\begin{array}{l}\text { Parents follow up adolescents' behaviors to detect } \\
\text { terrorist ideas. }\end{array}$ & 2.94 & 0.25 & Completely agree & 3 \\
\hline \multicolumn{2}{|r|}{ Overall } & 2.85 & 0.21 & Completely agree & \\
\hline
\end{tabular}

Table (12) shows significant suggestions that could be applied by family, including raising parents' awareness of the developmental characteristics, behavioral problems, and social and psychological pressures of various age stages. It is the most important family role that should be performed perfectly in all age stages. The second one is developing a sense of national belonging and loyalty to confirm nationalism and citizenship. It suggests appropriate political education of adolescents to develop nationalism and belonging. The item "parents follow up adolescents' behaviors to detect terrorist ideas" was ranked third. It highlights the family role of monitoring and following-up which should be performed perfectly to diagnose and handle any change of children's behaviors before turning into a serious problem. The participants suggested other methods, e.g. varying the tools of spending free time according to age and gender, following-up children to find out any new 
behaviors, guiding them to stick to religion in knowledge and practice, and asking Allah to bless them. This result matches the findings of AlHaj (2013), AlHawshan (2009), AlJahni (2008b), Assa'eedyn (2008) and AlMoisheer (2007).

\section{Recommendations}

- Highlighting the role of different educational and societal institutions in collaborating with family to prevent the prevalence of terrorist ideas.

- Holding seminars to raise parents' awareness of following-up adolescents to protect them against terrorist ideas.

- Holding courses and programs of reinforcing intellectual security and its positive consequences on individuals and society.

- Activating the role of research centers at universities and Ministry of Education to study all aspects of terrorism and find out the best practices of scientifically handling it.

- Establishing centers for family programs and engaging adolescents in social activities to help them spend free time usefully and not to adopt terrorist thought.

\section{References}

Abu Koora, K. (2013). The role of psychology in combating extremism and terrorism. Alrakoba Electronic Newspaper. Retrieved from archive.aawsat.com/details.asp?section=72\&article $=730595$ \&issueno $=12603$

Addagheem, M. (2006). Intellectual deviation and its impact on national security in the GCC countries. Riyadh: GCC

AlBakmy, F. (2010). The parent-child relationship and its role in preventing intellectual deviation: A case study adopting the grounded theory (Ph.D. dissertation.). Naif Arab University for Security Sciences, Riyadh.

AIGhamdy, S. (2005). Intellectual deviation and its impact on national security in the GCC countries. Riyadh: The Studies and Research Center, Naif Arab University for Security Sciences.

AlHaj, B. (2011). Family role in achieving intellectual security in the Algerian society. Journal of Law and Humanities, (9), 165-187.

AlHaj, H. (2013). Education role in protecting society against intellectual deviation. Journal of Red Sea University, (4), 177-202.

AlHawshan, B. (2009). The importance of family and school roles in protecting children against extremism and terrorism and reinforcing values of national belonging. Paper presented at the First National Conference on Intellectual Security. Riyadh: King Saud University.

AlHusseiny, A. (2005). Family education and its impact on protecting children against terrorist crimes. Security and Life, 24 (271), 52-57.

AlJahni, A. (2008a). Precipitants of intellectual deviation and terrorism. Journal of Justice, 39, $202-244$.

- (2008b). Intellectual deviation and social responsibility. Journal of Teachers College in Abha, 12, 5791.

AlKa'ood, Z. (2017). Women role in combating extremism and violence. Journal of Benghazi Modern University of Sciences and Humanities, (1) 18-26.

AlKhalifa, A. (2008). Family characteristics of family requested people and their relation to extremism and terrorism in Saudi society: A case study. Paper presented at The Scientific Forum of the Saudi Society of Sociology \& Social Work (The Saudi Family and Contemporary Changes). KSA: Al-Imam Muhammad Ibn Saud Islamic University.

Alkhamshy, S. (2004). Role of family education in protecting children against terrorism. Paper presented at Islam's position from terrorism (372-394). Riyadh: Imam Muhammad ibn Saud Islamic University.

AIMaghamsi, S. (2004). Dialogue education with young people and its impact on protecting them against intellectual and behavioral deviations ( $1^{\text {st }}$ ed.). Riyadh: Madar Al Watan for Publication.

AIMaliky, A. (2006). Towards developing a national strategy of intellectual security in facing terrorism (Ph.D. dissertation). Naif Arab University for Security Sciences, Riyadh.

AIMarwani, N. (2009). Successful international counter-terrorism experiences: The Saudi experience. A paper presented at the scientific seminar about the Ability of Security Systems and its Impact on Combating Terrorism. Riyadh: Naif Arab University for Security Sciences

AIMeleigy, S. (2013). Family role in combating terrorism and the importance of having dialogues with children. Security and Life, 33(380), 12-17.

AIMoisheer, M. (2007). Family role in achieving intellectual security (MA. thesis). Naif Arab University for Security Sciences, Riyadh. 
AIMo'gel, W. (2016). Family role in preventing intellectual extremism and violence among children and its relation to societal peace (Ph.D. dissertation). College of Social and Administrative Sciences, Naif Arab University for Security Sciences.

AIRashdy, O. (2012). The role of Saudi family in achieving preventive education against extremism according to SWOT applications. Journal of Educational Studies, (2), 233-300.

Assaleh, S. (2008). Educational responsibility of the family in achieving intellectual Security (M.A. thesis). Faculty of Da'wah and Fundamentals of Religion, Islamic University of Madinah.

Assa'eedyn, T. (2005). The role of educational institutions in preventing extremist thought. Journal of Security Research, 14(30), 15-62.

(2008). The educational role of family in preventing intellectual deviation. Journal of Security Research, $17(17), 40-71$

Assabea'y, S. (2006). Dissemination of takfirism: Factors, effects and combating (MA. thesis). Naif Arab University for Security Sciences, Riyadh.

Attaweel, L. (2016). Da'wah responsibility of the family in protecting children against terrorism and violence. North Journal of Humanities, 1(2), 3-28.

Banjar, A. (2006). The educational role of gulf families in protecting their children against exaggeration and extremism: An Islamic educational perspective. Future of Arabic Education, 12(43), 133-184.

Chemiss, C. (2000). Emotional intelligence: Why it is and why it matters. A paper presented at the Annual Meeting of Society for Industrial and Organizational Psychology. New Orleans: Consortium for Research on Emotional Intelligence in Organizations.

Dawood, M. (2015). Women role in raising societal awareness of violence and extremism. A paper presented at the conference of "She and Terrorism".

Halawa, B. (2001). Parents' role in forming the social personality of children: A field study. Journal of Damascus University, 27 (3-4), 71-109.

Lazem, A. (2015). The role of educational curricula in facing terrorism and intellectual deviation. Paper presented at the Second Conference of the College of Basic Education "Discourse of Art and Language in Facing Intellectual Terrorism" (pp. 929-948). Iraq: University of Misan.

Mojahid, A. (2005). Scientific prediction as a basis of security planning. Cairo: Dar Alausrah.

Mustafa, H. (2008). The role of Arab satellite channels in forming the audience's knowledge and attitudes towards terrorism: A field study on a sample of Arab audience. The Arab Radio Review, (3-4), 62-67.

Sabbagh, C. (2005). Environmentalism, right-wing extremism, and social justice beliefs among East German adolescents. International Journal of Psychology, 40, 118-131.

Salem, A. (2018). Intellectual deviation and development: Definition, reasons, motives, dimensions and combating. Retrieved from: https://www.policemc.gov.bh/.../0f7f75fd-e512-42ec-a018-b5a2714e76f3

Shradika, T. (2016). The role of the media in combating terrorism and extremism: A field study. A paper presented at the International Conference "The Role of Sharia, Law and Media in Combating Terrorism: A World without Terrorism", Jordan: Zarqa University.

The Basic Law of Governance. (1992). Retrieved from https://www.marefa.org

United Nations Office of Counter-Terrorism (2006). United Nations General Assembly Adopts Global CounterTerrorism Strategy. Retrieved from https://www.un.org/counterterrorism/ctitf/en/united-nations-generalassembly-adopts-global-counter-terrorism-strategy

Zain-ul-abedeen, F. (2015). The role of family and civil society institutions in preventing extremism and terrorism: A field study on the Jordanian society. Al-Arabiya, 3(163), 685-723. 